\title{
Baladas de la memoria de Pedro Lastra
}

Valencia: Pre-Textos, 2010. 111 págs.

RoberTo ONELl H. Pontificia Universidad Católica de Chile Santiago, Chile ronell@uc.cl

Dedro Lastra (Quillota, Chile; 1932) es autor de una solvente bibliografía. 1 Diremos, sólo para contextualizar, que al menos cuatro tipos de obras se distinguen en esa nutrida lista: por una parte, sus propios versos, acaso su más íntima creación, que han recibido diversos estudios, como los reunidos por Silvia Nagy-Zekmi y Luis Correa Díaz con el título Arte de vivir (Santiago: Dibam, Ril; 2006), y la monografía de Edgar O'Hara La precaución y la vigilancia (la poesía de Pedro Lastra) (Valdivia: Barba de Palo, 1996); por otra parte, los textos ensayísticos sobre la literatura hispanoamericana en general, como Relecturas hispanoamericanas (1987), Asedios a Oscar Hahn (1989, en coedición con Enrique Lihn), Leído y anotado (1998), Invitación a la lectura (2001); después, las diversas antologías que ha editado, como $E l$ cuento hispanoamericano del siglo XIX: notas y documentos (1972), Muestra de la poesia hispanoamericana actual (ensayo, crítica y antología) (1973), Antología del cuento chileno (1974), Antología crítica de Julio Cortázar (1981), Crónica de varia lección (2000; antología de Ricardo Latcham, en coedición con Alfonso Calderón y Pedro Pablo Zegers), Poesía esencial (2001, antología de Gonzalo Rojas), Presencia de Grecia en la poesía hispanoamericana (2004, en coedición con Rigas Kappatos), Cuentos fantásticos y extraños (2008, antología de Rubén Darío), César Vallejo: una lectura desde Chile (2009, antología consultada); y finalmente, los fecundos diálogos como Conversaciones con Enrique Lihn (1980, reeditado en 2009 con un texto inédito de Lihn) y Cartas de José María Arguedas a Pedro Lastra (1997, editado por Edgar O'Hara). El volumen Obras selectas (Santiago: Andrés Bello, 2008) consigue una valiosa sinopsis de esta larga convivencia con las palabras y las letras.

Lastra es autor de los poemarios La sangre en alto (1954), Traslado a la mañana (1959), Y éramos inmortales (1969), Noticias del extranjero (1979) 
y Canción del pasajero (2001), descontando los diversos volúmenes antológicos en los que agrega algún nuevo poema. En un procedimiento que conocimos, por ejemplo, con Gonzalo Rojas, cada nueva publicación de poesía de Pedro Lastra incluye un número variable, pero siempre menor que el resto de los textos, de poemas hasta entonces inéditos. A modo de ejemplo, véanse los títulos: Leve canción y Notas de viaje, antologías traducidas respectivamente al italiano, Lieve canzone, y al inglés, Travel notes; o el mismo Noticias del extranjero, cuyas sucesivas reediciones han engrosado la lista de poemas de la edición príncipe. La opción de agregar unos pocos poemas a conjuntos mayores de ellos, y sólo de cuando en cuando entregar un conjunto enteramente nuevo, constituye una elocuente señal del modo como Lastra concibe y ejecuta su trabajo poético: la poesía, por ser una tradición, es condición de posibilidad de su misma renovación. De ahí que estas muestras poéticas sean una instancia privilegiada para ponderar cada nuevo poema en el conjunto de la poesía de Lastra, como también para averiguar la ponderación que el mismo autor da a sus diversos textos; tanto los elegidos como los descartados se reubican. Y así, varias veces antologado y traducido en América y Europa, las últimas apariciones antológicas en forma individual de Pedro Lastra son Diálogos del porvenir (Santiago: Pfeiffer, 2010), que incluyó "Diálogo con Irene" y "Recuerdos del mal pasado", y el título que ahora nos convoca.

Baladas de la memoria nos presenta una nueva muestra de la poesía ya publicada de Pedro Lastra, más algunos poemas inéditos hasta aquí. Escogida por Irene Mardones y Miguel Gomes, la selección ofrece 87 poemas en total, que transcurren en la simplicidad de una secuencia sin prólogo ni subconjuntos. Sin más presentaciones que la sencilla y cuidada factura del libro como objeto, en cuya portada vemos el dibujo, en negro sobre fondo color hueso, de un tigre que avanza de frente al lector, pero mirando hacia el lado, y una breve descripción firmada por el editor en contratapa, seguida de un elogio firmado por Gonzalo Rojas, somos convocados al encuentro con textos justamente antológicos de Lastra. Por ejemplo: "Ya hablaremos de nuestra juventud" (10), temprana anticipación del olvido; "Reflexiones de Aquiles" (15), uno de los muchos préstamos de voz de Lastra a personajes específicos; "Estudio" (17), cuadro de la serena cotidianidad de una mano de mujer; "Canción del pasajero" (19), donde Eugenio Montejo se despide de un mundo tecnificado y ruidoso; "Noticias del maestro Ricardo Latcham, muerto en La Habana" (21-23), homenaje de un discípulo agradecido; "Puentes levadizos" (25), que pregunta por un rey llamado Óscar Hahn; "Relectura de Enrique Lihn" (27), recuerdo de amistad fraterna; "Palabras 
a Víctor Jara" (30), homenaje a la maravilla del canto; "Para el nuevo decálogo" (47), mandamiento acerca del amor; "Copla" (49), señero ejemplo de concentración; "El azar" (52), pregunta, pormenorizada con alternativas de existencia, dirigida a un tú originario; "Don Quijote impugna a los comentadores de Cervantes por razones puramente personales" (53), donde el hidalgo defiende la veracidad de su amor a Dulcinea y cita a Vallejo; el excelente soneto "Mester de perrería" (54); "Contracopla" (66), otro ejemplo de concisión; "El exilio o el reino" (74), defensa del amor contra la ira de los dioses; "Leve canción" (82), fina celebración de una presencia inminente; "Última copla" (87) o la pertinacia del amor; "Nadie" (93), recuerdo de Ulises y desciframiento de ese nombre suyo.

Baladas de la memoria contiene seis poemas estrictamente inéditos hasta ahora, que conviene reseñar, así sea brevemente, en sus características más notables. El poema "Al margen de Darío" (95) presenta a un hablante llamado "Pedro" que, engañado por "los falsos mercaderes del templo", pide perdón al "maestro" Rubén Darío por haberlo negado "tres veces", hasta por fin reconocer la verdad de su magisterio; similar anagnórisis es confesada en "Resplandor" (96), poema que recuerda, por parte de un nosotros, una "imagen" pasada cuyo "fulgor" revela algo capital en el presente; "Curso y recurso" (97), en abierta referencia al corsi e recorsi de Giambattista Vico, reproduce esa misma dualidad en dísticos que invitan a dejar "actuar el viento [...] de la historia", porque "él sabe lo que hace"; "Canción del alebrije" (99), por su parte, nos entrega la pregunta por la propia identidad del alebrije como creación, con una meditación acerca de la paternidad del "escultor, mi padre", y acerca del ser así desvelado; "Del único elemento" (100), a su vez, es un poema sobre ese material que resta "del fuego nunca inmóvil", como un resto que ayuda a vivir; "Lobos y pájaros en Cobquecura” (101), epigramático, estoico, admira la serenidad que dichos animales, avistados en ese pueblo costero, demuestran ante el morir. La versificación se mantiene tanto en el recurso como en la prescindencia de la métrica, en poemas que, una vez más en Lastra, optaron muchas veces por la brevedad de media carilla o menos. Y, como también es habitual en esta poesía, estas seis composiciones nos permiten el encuentro con otros autores y obras que, en trazos explícitos e implícitos, vienen a nutrir la presente escritura y, asimismo, a ser reformulados por la particular lectura de Lastra en cada uno de sus hablantes.

La alternancia que observamos entre el compás métrico y la cadencia más bien prosística, en la entera poesía de Pedro Lastra, permiten explicar el sostenido ritmo que percibimos cada vez. Tanto en esquemas rigurosos de 
versificación, como el soneto, cuanto en la combinación irregular de medidas versales, y aun en los versos que evitan todo metro y acentuación tradicional, la escritura de Lastra comunica una regularidad rítmica de notable consistencia. Ello es todavía más destacable si advertimos que su ánimo es frecuentemente conversacional, que no asociaríamos a la sonoridad acompasada. Los poemas de Lastra pueden tener un tono serio, de cierta solemnidad y gravedad incluso, o bien, contagiar una serenidad y un espíritu lúdico de largo alcance, pero casi siempre en el ritmo de una conversación. Los hablantes de esta poesía tienen a otro hablante al frente, que permanece en silencio, oyendo al primero. Por eso puede, pertinentemente, denominarse baladas al conjunto de composiciones, y destacarse la memoria como uno de los grandes tópicos de la poesía lastriana. Ya sea como recurrencia memorialista, ya sea como espacio de oscilación del olvido, en el compás y en la cadencia la memoria es aquí positivamente una instancia de encuentro, y ello significa instancia de búsqueda y hallazgo de los otros: vivir es convivir. Una memoria que se presenta de maneras diversas: meditación, tranquila e inquieta, sobre el tiempo; distinción entre vida y escritura, que a menudo deviene en alimentación recíproca; presencia de los otros seres humanos, los de la vida (pareja, amigos, parientes) y los de la escritura (autores, personajes, citas). Pero, así como esta poesía conversa con otro que la oye, así también ella escucha: los poemas de Lastra tienen ese tono leve y solemne, porque cuentan con una tradición que, al ser escuchada, es asumida. Es el rigor de la escucha; el yo que puede decir yo porque se percibe parte de una historia de voces. De ahí la falta de estridencia y de irreverencia, y también la bienhechora falta de irrelevancia y de banalidad. Y más importante: la plenitud de concentración, donde volvemos a comprendernos, interpelados como si fuera primera vez. Por eso esta poesía, como el tigre de la portada, también nos escucha. 